\title{
Practical Predictability of the 17 December 2014 Heavy Rainfall Event over East Coast of Peninsular Malaysia using WRF Model
}

(Kebolehramalan Praktikal Peristiwa Hujan Lebat pada 17 Disember 2014

di Pantai Timur Semenanjung Malaysia menggunakan Model WRF)

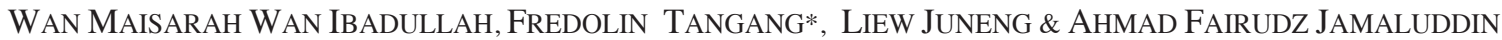

\begin{abstract}
An investigation on the practical predictability aspects of heavy rainfall event in the east coast states of Peninsular Malaysia was carried out by simulating the 17 December 2014 episode using the Weather Research and Forecasting (WRF). The WRF model was configured with three nested domains of $36 \mathrm{~km}, 12 \mathrm{~km}$, and $4 \mathrm{~km}$ horizontal resolution for $36 \mathrm{~h}$ simulations. It was found that the cumulative rainfall amount and the location of the heavy rainfall centre are sensitive to the choices of Cumulus Parameterisation Scheme (CPS). The experiment with a resolution of $4 \mathrm{~km}$ that used the multiscale Kain-Fritsch for the outer domains and no cumulus scheme in the inner domain reasonably well simulated the case. Further analysis suggests that the CPS and initialisation gave larger impact to the forecast quality compared to boundary conditions. Grid resolution contributed the least error.
\end{abstract}

Keywords: Cumulus schemes; East Coast Peninsular Malaysia; heavy rainfall episode; practical predictability; WRF model

ABSTRAK

Kajian ke atas kebolehramalan praktikal peristiwa hujan lebat di Pantai Timur Semenanjung Malaysia dilakukan dengan mensimulasi episod hujan lebat pada 17 Disember 2014 menggunakan model berangka Weather Research and Forecasting (WRF). Konfigurasi model WRF adalah tiga domain tersarang dengan resolusi mendatar $36 \mathrm{~km}, 12 \mathrm{~km}$ dan $4 \mathrm{~km}$. Simulasi dijalankan bagi tempoh 36 jam bermula pada 12 UTC 16 Disember 2014 sehingga 00 UTC 18 Disember 2014. Daripada segi kebolehramalan praktikal, kajian ini mendapati keamatan hujan terkumpul dan lokasi pusat hujan lebat bergantung kepada pemilihan skim pemparameteran kumulus. Model WRF dengan resolusi 4 km dan gabungan skim kumulus berbilang skala Kain-Fritsch untuk dua domain terluar dan tanpa skim kumulus untuk domain dalam berupaya untuk mensimulasikan kejadian tersebut dengan baik. Kajian juga mendapati perubahan skim kumulus diikuti dengan syarat awal memberikan kesan yang lebih besar terhadap kualiti ramalan berbanding syarat sempadan. Manakala kesan resolusi grid menunjukkan ralat yang paling kecil.

Kata kunci: Episod hujan lebat; kebolehramalan praktikal; model WRF; Pantai Timur Semenanjung Malaysia; skim kumulus

\section{INTRODUCTION}

In light of possible intensification of extreme precipitation due to climate change (Field et al. 2012; Tangang et al. 2018) and climate variability (Tangang et al. 2017, 2012), an improvement in prediction skills of extreme events, especially those lead to severe and widespread flooding, is a crucial aspect to consider in any disaster risk reduction (DRR) programme. Located in the western part of the Maritime Continent, Malaysia has been frequently impacted by severe flooding, especially during the boreal winter monsoon (Chen et al. 2013; Juneng et al. 2007; Ooi et al. 2017; Tangang et al. 2008). In the east coast of Peninsular Malaysia, heavy precipitation events are common during this period, occasionally causing severe and widespread flooding in the area. The flood that occurred in southern Peninsular Malaysia during midDecember 2006 to late January 2007 had affected more than 200,000 people, with estimated economic losses of
USD 500 million (Tangang et al. 2008). The flood was considered as the worst in a century, until the December 2014 flood that affected the northeastern region of Peninsular Malaysia superseded it. The severity of the latter event was much worse, where the extent of affected area was much wider. The December 2014 flood affected more than 250,000 people and caused much higher economic losses (Ooi et al. 2017). With a possibility of re-occurrence and intensification of such extreme weather events in the future, it is imperative for Malaysia to have a reliable and skilful early warning system of both weather and flood events. Accurate prediction of the timing, location and intensity of extreme weather events at a sufficient lead time is critical for a skilful flood forecast, which will help the authorities to implement necessary actions well in advance and minimize the disaster risk.

Despite the urgent and crucial needs for skilful forecasts, research and developmental works to improve 
numerical weather prediction (NWP) over this region appear limited (Juneng et al. 2007; Salimun et al. 2010; Yavinchan et al. 2011). These earlier studies focused merely on assessing the performance of certain parameterization schemes, and process understanding. However, prediction of extreme weather in the tropics is very challenging because of the relative importance of local and mesoscale effects compared to the synoptic scale. For better prediction skill, a model must be able to properly represent moist convection at smaller scales. In Juneng et al. (2007), Salimun et al. (2010), and Yavinchan et al. (2011), overestimation of heavy rainfall was a common issue. For NWP model forecast skill improvement, holistic understanding of errors and their growth is needed (Zhang et al. 2006) and this aspect has yet to be researched adequately over this region. In mid-latitude region, Zhang et al. (2006) reported the limitations of mesoscale model predictability for extreme precipitation event, which can be of practical and intrinsic origins. The intrinsic predictability refers to the extent to which the prediction is possible assuming nearly perfect dynamical model and initial-boundary conditions. On the other hand, the practical predictability is the ability to predict based on the currently available procedure, which is limited by realistic uncertainties in the initial state and the numerical models formulation (Zhang et al. 2006). Because of the limitation of intrinsic predictability even when perfect model is assumed (Taraphdar et al. 2014; Zhang et al. 2003), forecast skills may be improved by focusing on the practical predictability aspects. Hence, the purpose of this study was to comprehensively examine the practical predictability of the 17 December 2014 extreme rainfall event over the northeastern Peninsular Malaysia using Weather Research Forecasting (WRF) model. The findings of this study could provide a useful basis for improvement of NWP forecast and early warning system in Malaysia, a critical component of DRR.

\section{CASE DESCRIPTION}

During the 2014 winter monsoon season, there were three cold surge episodes that induced extreme rainfall events between November and December 2014 on the east coast of Peninsular Malaysia, including the 13-20 November 2014, 14-19 December 2014, and 20-24 December 2014 episodes (Ooi et al. 2017). The most intense rainfall event that affected the east coast states of Peninsular Malaysia occurred during the second episode. To further investigate the temporal variation of the heavy rainfall event, maximum daily rainfall (MDR) (mm/day) over $101.9^{\circ} \mathrm{E}-102.7^{\circ} \mathrm{E} ; 5.3^{\circ} \mathrm{N}-6.4^{\circ} \mathrm{N}$ (Figure $1(\mathrm{a})$ ) in December 2014 was examined using rainfall data from the Tropical Rainfall Measuring Mission TRMM3B42 (TRMM) (Huffman et al. 2007). The MDR shows that the heavy rainfall events occurred between 14 and 29 December 2014, with three pronounced peaks on 14 December, 17 December, and 23 December (not shown). The highest rainfall recorded was on 17 December 2014 in northern
Kelantan, which led to the most extreme ever recorded in the area (Ooi et al. 2017). As shown Figure 1(a), the $24 \mathrm{~h}$ accumulated rainfall was highest in the northeast corner of Peninsular Malaysia, including the eastern part of southern Thailand. The area that received the highest accumulated rainfall was along the coast, where there is elevated topography to the west of this area (Figure 1(a)). The convergence of rainfall over this region may be enhanced by the topographic blocking as noted in Juneng et al. (2007) for a different episode.

Figure 1(b) shows the three-hourly accumulated rainfall at three stations (Figure 1(a)) based on the raingauge data and the area-averaged TRMM rainfall over the box shown in Figure 1(a). Both Kota Bharu and Gong Kedak stations recorded consistently lower rainfall since beginning of the day but the rain rate at both stations increased rapidly after 1200 UTC, where more than 75\% of the daily rainfall fell during later half of the day. In comparison, Kuala Krai recorded higher amount of rainfall during the first half of the day, while the rain rate reduced remarkably after 1200 UTC. The differences in rainfall timing between the three stations could be due to their locations. Both Gong Kedak and Kota Bharu are located nearer to the coast, while Kuala Krai is located in the interior of Kelantan State (Figure 1(a)) and more affected by the convergence induced by the presence of elevated topography to the west of it. The area-averaged TRMM rainfall showed comparable rainfall to that recorded at the Kota Bharu and Gong Kedak stations in the early part of the day. However, area-averaged rain rate showed marked increased between 0900 and 1200 UTC, where the accumulated rainfall tripled at 1200 UTC. Based on the Malaysia Meteorological Department's composite radar images (not shown), at the beginning of the day, there were two centres of rain clusters along the coast of Peninsular Malaysia in the north and the south, which the centres then merged along the coast. The estimated maximum rain rate of these radar data was recorded between 0600 UTC and 1200 UTC on 17 December 2014, consistent with the rain-gauge accumulated rainfall shown in Figure 1(a). By 1500 UTC, the rainfall over the northern areas started to decrease, and later by 1800 UTC the offshore rain band approached the coastline of the southern-central east coast of Peninsular Malaysia, increasing the intensity of the rainfall along the coast. Throughout the day, heavy rainfall was recorded in the northern coastal areas as shown in the TRMM accumulated $24 \mathrm{~h}$ rainfall (Figure 1(a)). The rainfall distribution pattern over the study area may well be correlated with the synoptic circulation during the episode. Readers are pointed to Ooi et al. (2017) who have carried out detailed synoptic analysis of the episode.

\section{MODEL CONFIGURATION AND EXPERIMENTAL DESIGN}

Various simulations of the 17 December 2014 heavy rainfall event were performed with the Weather Research Forecasting (WRF) model version 3.7.1 (Skamarock et al. 
(a)

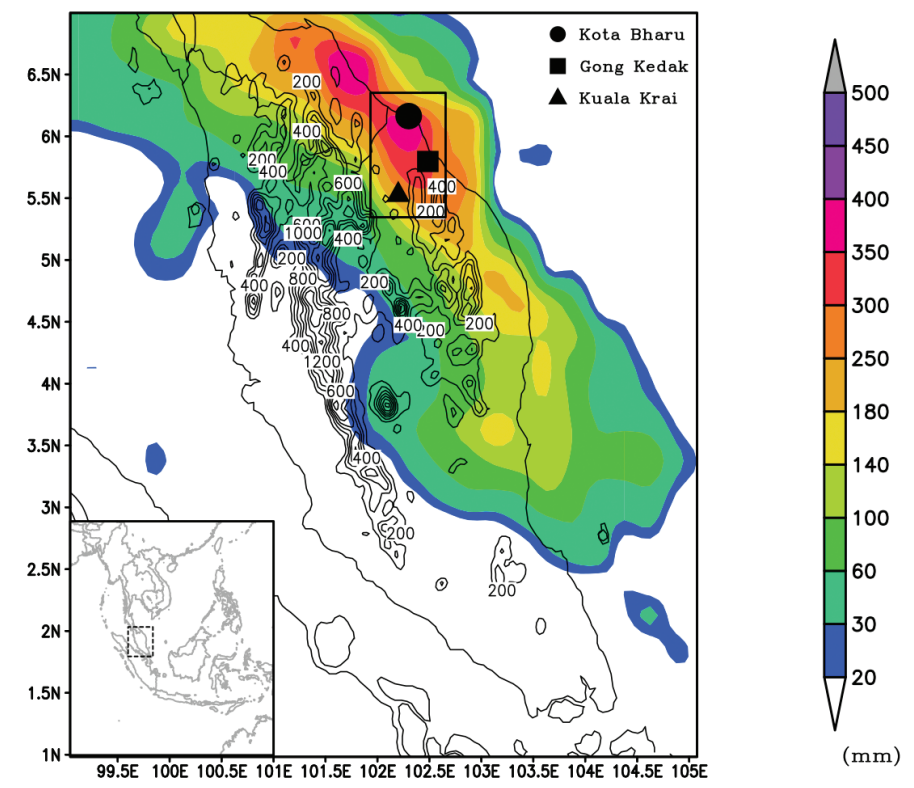

(b)

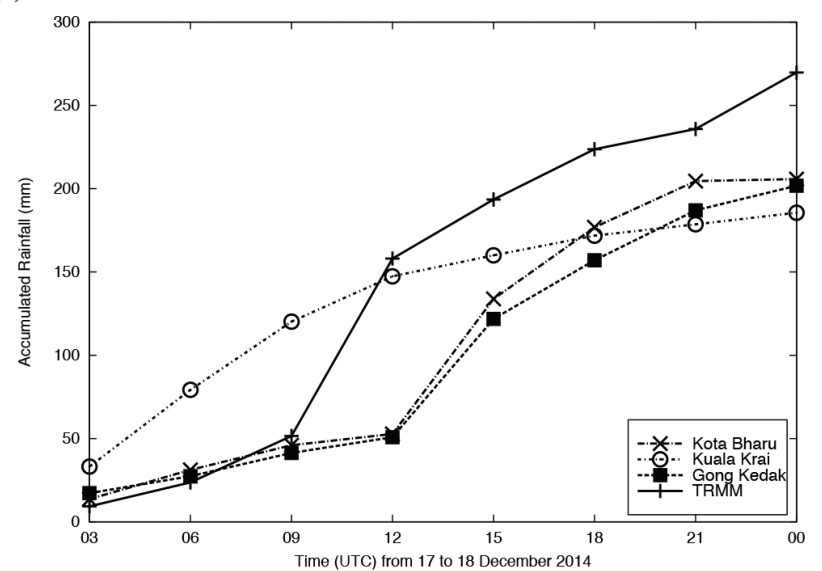

FIGURE 1. (a) The approximate location of the three stations overlaid with $24 \mathrm{~h}$ accumulated rainfall (mm) from TRMM on 17 December 2014, and terrain elevation, (b) The $3 \mathrm{~h}$ accumulated rainfall (mm) on 17 December 2014 recorded in Gong Kedak, Kota Bharu, and Kuala Krai and area-averaged TRMM rainfall (box in (a))

2008). WRF had been used in many simulation studies of extreme precipitation events around the world (Ardie et al. 2012; Jankov et al. 2005; Kumar et al. 2008). The model was integrated over $36 \mathrm{~h}$, from 1200 UTC 16 December 2014 to 0000 UTC 18 December 2014. The initial and boundary conditions used for this simulation were obtained from the analyses of the Global Forecast System (GFS) model with a resolution of $0.5^{\circ} \times 0.5^{\circ}$ and were updated at $6 \mathrm{~h}$ intervals. The simulations were conducted using a triple-nested domain configuration with horizontal resolutions of $36 \mathrm{~km}, 12 \mathrm{~km}$, and $4 \mathrm{~km}$ for the outer (D01), middle (D02), and inner domain (D03), respectively (Figure 2). The simulations were set up in a two-way nesting configuration where feedbacks between the child and the parent domains were allowed. All domains were configured with 30 vertical levels, with the top pressure level set at $50 \mathrm{hPa}$.
The first experiment was to determine the effectiveness of different cumulus parameterisation schemes (CPSs). These CPSs include Kain-Fritsch (KF) (Kain 2004), Betts-Miller-Janjic (BMJ) (Janjic 1994), multi-scale Kain-Fritsch (MKF) (Zheng et al. 2016), new simplified Arakawa-Schubert (NS) (Han \& Pan 2011), and the new Tiedtke scheme (NT). The KF, BMJ, and Arakawa-Schubert schemes are widely used in tropical weather prediction (Ardie et al. 2012; Kumar et al. 2008; Salimun et al. 2010; Yavinchan et al. 2011). The combinations of these CPSs in all three different domains are denoted as Experiments 1 to 10 (EXP 1 to 10, Table 1). For the innermost domain, an explicit simulation without the cumulus parameterisation was also considered (EXP 1, 3, 5, 7 and 9). For all of simulations, other physics options were made identical across domains. These include the WRF Single-Moment 3-class (WSM3) scheme for the microphysics (Hong et al. 


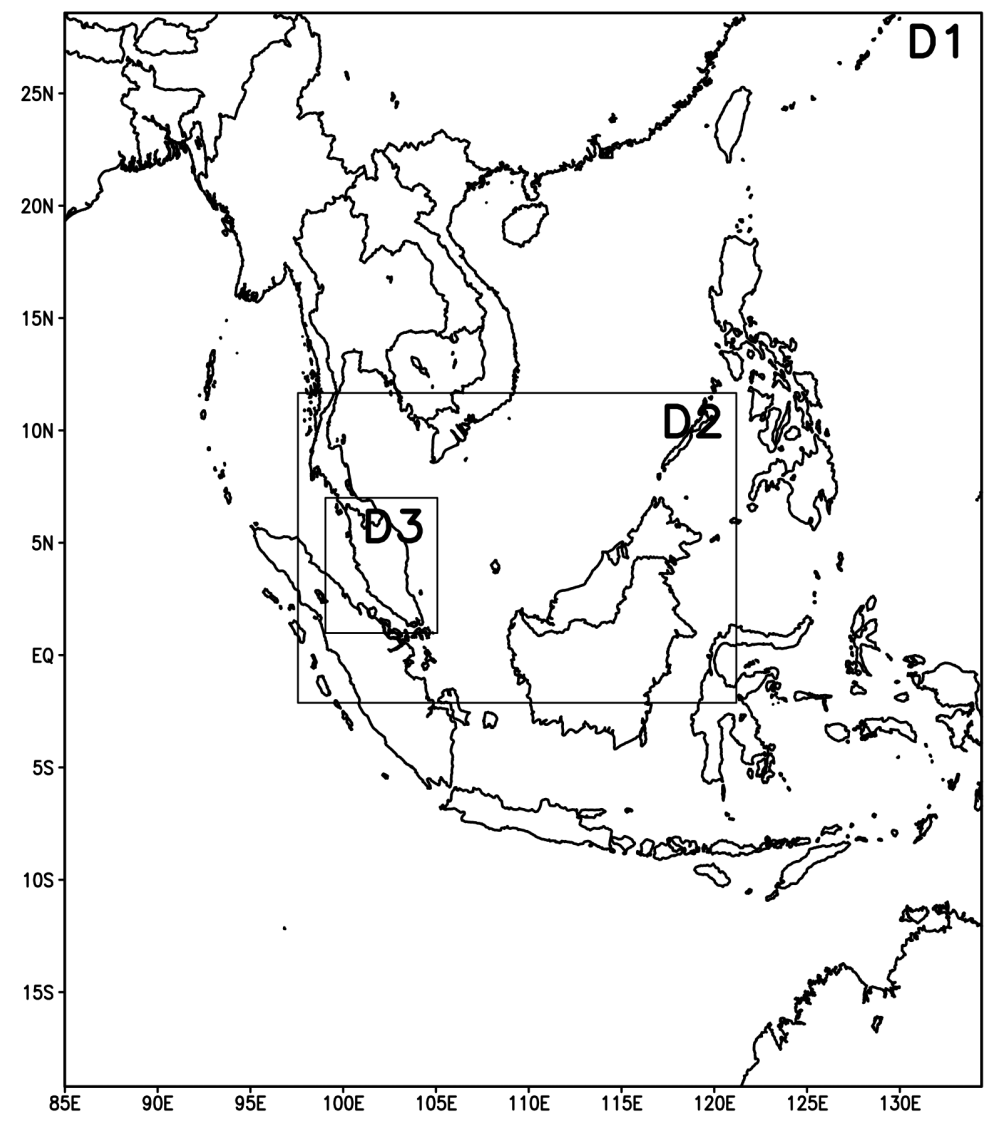

FIGURE 2. Three nested domains configuration of the WRF simulation

TABLE 1. List of experiments of different combinations of cumulus parameterization schemes

\begin{tabular}{cccc}
\hline \multirow{2}{*}{$\begin{array}{c}\text { Experiment } \\
(\text { EXP) }\end{array}$} & \multicolumn{3}{c}{ Parameterization schemes } \\
\cline { 2 - 4 } & Domain 1 & Domain 2 & Domain 3 \\
\hline 1 & KF & KF & None \\
2 & KF & KF & KF \\
3 & BMJ & BMJ & None \\
4 & BMJ & BMJ & BMJ \\
5 & MKF & MKF & None \\
6 & MKF & MKF & MKF \\
7 & NS & NS & None \\
8 & NS & NS & NS \\
9 & NT & NT & None \\
10 & NT & NT & NT \\
\hline
\end{tabular}

2004), the rapid radiative transfer model (RRTM) scheme for long-wave radiation (Mlawer et al. 1997), the Dudhia scheme for the atmospheric shortwave radiation (Dudhia 1989), the 5-layer thermal diffusion for the land surface (Dudhia 1996), and the Yonsei University scheme for the planetary boundary layer (Hong et al. 2006). Based on this experiment, we adopted the EXP5, which used explicit scheme in D03 and multi-scale Kain-Fritsch CPS in both outer domains, as a control experiment (CNTL). While the first experiment identifies the most appropriate CPS to use, the second experiment (Table 2) details out the sensitivities to the changes in initial states, boundary conditions and grid resolutions.

TABLE 2. List of experiments for investigating different aspects of practical predictability

\begin{tabular}{llcc}
\hline EXP & \multicolumn{1}{c}{$\begin{array}{c}\text { Grid spacing in km } \\
(\text { Cumulus scheme })\end{array}$} & Initial analysis & Lateral boundary \\
\hline CNTL & $36(\mathrm{MKF}), 12(\mathrm{MKF}), 4($ none $)$ & GFS & GFS \\
RCTL & $36(\mathrm{MKF}), 12(\mathrm{MKF}), 4(\mathrm{MKF})$ & GFS & GFS \\
ERAic & $36(\mathrm{MKF}), 12(\mathrm{MKF}), 4(\mathrm{none})$ & ERA-Interim & GFS \\
ERAbc & $36(\mathrm{MKF}), 12(\mathrm{MKF}), 4(\mathrm{none})$ & GFS & ECMWF \\
RES1 & $36(\mathrm{MKF})$ & GFS & GFS \\
RES2 & $36(\mathrm{MKF}), 12(\mathrm{MKF})$ & GFS & GFS \\
BMJcps & $36(\mathrm{BMJ}), 12(\mathrm{BMJ}), 4($ none $)$ & GFS & GFS \\
\hline
\end{tabular}




\section{RESULTS AND DISCUSSION}

\section{SENSITIVITY TO CUMULUS PARAMETERIZATION SCHEMES}

Figure 3 shows the 24 h cumulative rainfall (0000 UTC 17 December 2014 to 0000 UTC 18 December 2014) over D03 for all experiments. Also shown is the corresponding rainfall from TRMM. There is a large inter-experiment variation, reflecting different performances and a high sensitivity to the cumulus parameterization scheme used. Noticeably, all experiments underestimated the TRMM precipitation. It can be seen that EXP5 and EXP6 gave relatively high amplitude of rainfall. EXP5 also showed the closest spatial pattern compared to TRMM where the rain band along the coastal of Peninsular Malaysia and the maximum rainfall in the northern part were simulated reasonably. However, the position of the maximum rainfall was shifted slightly inland compared to TRMM. Despite having a slightly lower amount of rainfall, EXP2 appears to have the correct location of the maximum rainfall i.e. over the coastal area of northeast Peninsular Malaysia.

Figure 4(a) shows the three-hourly accumulated rainfall where EXP5 is the only experiment that closely attained the observed accumulated rainfall. Furthermore, the inland shift of the maximum rainfall is considered less serious than the underestimation of rainfall amount. Since the ability to forecast the intensity of the extreme rainfall episode is crucial, especially when the forecast output is subsequently used for operational weather forecast warnings and flood forecasting, we adopted EXP5 as the control experiment (CNTL) for subsequent analyses.

The MKF, which was used in EXP5, performs better than other schemes in simulating the heavy rainfall episode. The BMJ (EXP 3 and 4) was not able to reproduce the location and intensity of this extreme event. Therefore, the BMJ performance in this study was considered inferior compared with previous studies using the older Betts-
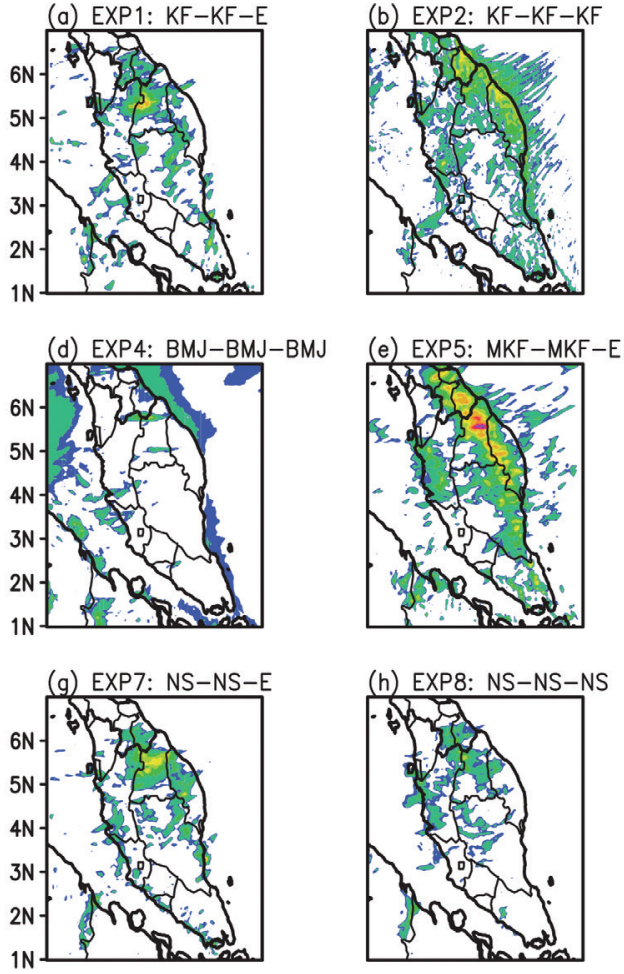
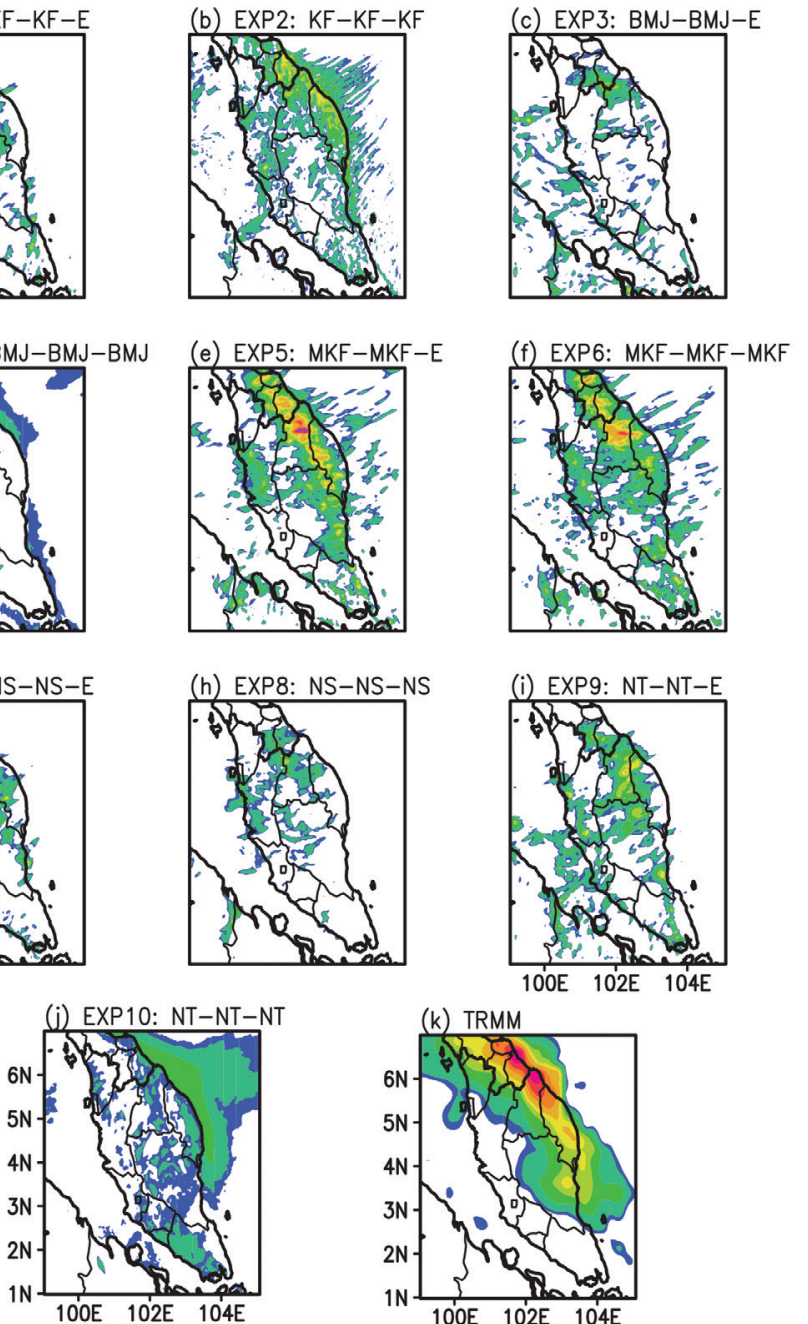
Miller (BM) scheme (Salimun et al. 2010), which was used for a simulation of coarser resolution of $15 \mathrm{~km}$. This might be due to the dependency on a single stable humidity profile and disregard of cloud dynamics in the Betts-Miller convective adjustment scheme (Kerkhoven et al.2006) from which BMJ was derived. However, the KF (EXP2) performed slightly better, as found in a previous study for simulations at $5 \mathrm{~km}$ resolution (Yavinchan et al. 2011). The KF CPS is a mass-flux parameterization modified from the previous KF scheme (Kain \& Fritsch 1993). The modifications include the updraft and downdraft formulation, and closure assumption (Kain 2004). The MKF, on the other hand, is the updated 'scaleaware' version of the KF CPS, taking into account the need of 'scale-aware' implementations of convective physics in the model (Arakawa \& Jung 2011). Improvements in the MKF scheme include dynamic adjustment of time scale, enhancement of grid-scale vertical velocity, and entrainment methodology based on lifting condensation level (LCL) (Zheng et al. 2016). The superior performance of MKF in this study can be due to these features. On the other hand, in the original version of KF these parameters were fixed for a grid spacing of around $25 \mathrm{~km}$, which may not be suitable for the $4 \mathrm{~km}$ simulations. The use of MKF showed improvement in predicting extreme rainfall events in previous studies (Mahoney 2016).

\section{PRACTICAL PREDICTABILITY}

In this section, the results of experiments on the effect of aspects including grid resolution, initial and boundary conditions on the predictability are presented. Figure 5(a)5(c) shows the simulated rainfall in all three domains i.e. D01 (RES1, $36 \mathrm{~km}$ ), D02 (RES2, $12 \mathrm{~km}$ ), and D03 (RCTL, $4 \mathrm{~km}$ ), where the same CPS (i.e. MKF) was used across different domains. As can be seen in these figures, the location of the maximum rainfall for all domains does not show notable differences among the simulations. However, there is a clear difference in the intensity, where the value tended to increase with resolution. The RCTL run at $4 \mathrm{~km}$ resolution has the second-highest intensity compared to the rest of the simulation experiments (Figure 4(a)). Based on the maximum rainfall, RES1 only predicted about half the rainfall, compared to RCTL. In RES2, there was an increment in the maximum rainfall compared to RES1, although the value was still lower than RCTL.

The 3 hourly averaged rainfall and accumulated averaged rainfall of the resolution experiments, for the box area indicated in Figure 1(a), is shown in Figure 4(b)-4(c). Both figures indicate that the 3-hourly rainfall and accumulated rainfall, averaged over the box, differ minimally among the three domains. Hence, this result suggests, based on the chosen box, the effects of different resolutions on the forecast appear to be minimal. However, as discussed above, the performances appear markedly different when simulating the maximum rainfall, where the high-resolution D03 of $4 \mathrm{~km}$ produced a much higher intensity. For operational forecasts and flood forecasting, correctly simulating the intensity (or maximum rainfall) is considered very crucial. These results shows that a higher resolution provides a relatively skilful prediction, as the model resolves moist physics better with the increment of grid resolution (Zhang et al. 2002). Additionally, based on Figure 4(a), the 3 hourly simulated rainfall showed increments for up to $21 \mathrm{~h}$ and a decrement afterwards. This decrement appears to be consistent with the radar images (not shown) and the observed data from the station rain gauge (Figure 1). This comparison also suggests that TRMM may overestimate the actual amount of rainfall during the episode.

(a)

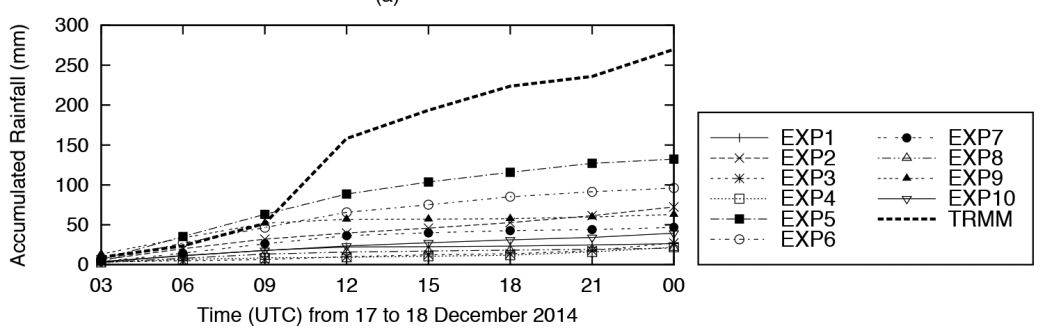

(b)
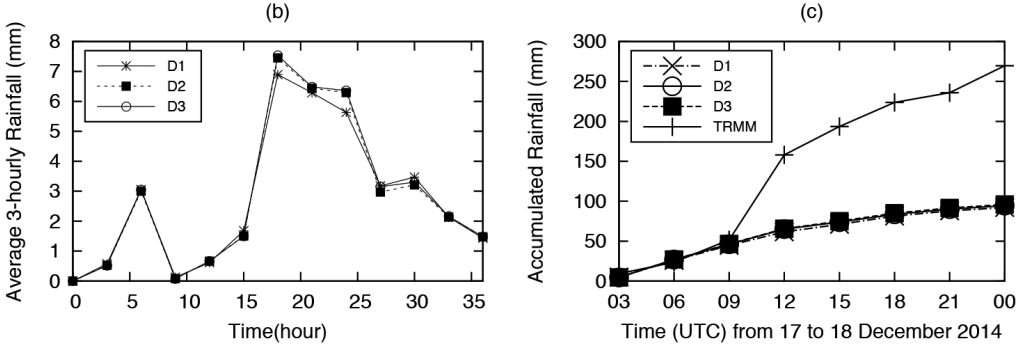

FIGURE 4. (a) The 3 hourly accumulated rainfall ( $\mathrm{mm})$ of D03 for various combinations of different cumulus parameterizations (refer to Table 1) and TRMM, (b) Time evolution of 3 hourly averaged rainfall (mm) for RES1 (D01), RES2 (D02), and RCTL (D03), and (c) Accumulated averaged rainfall

(mm) for RES1 (D01), RES2 (D02), RCTL (D03), and TRMM over the box area in Figure 1(a) 
In the initial and boundary condition experiments (Table 2), ERAic and ERAbc are identical to CNTL except in ERAic, ERA-Interim data was used to initialise the simulation, while for ERAbc, the ERA-Interim data was used as the boundary conditions (Table 2). The location of the simulated rainfall in ERAic was improved slightly, in which the southern extent of the rain band was located closer to the coastal region (Figure 5(d)). Also, the superficial rainfall patch over the western coast of Peninsular Malaysia was not simulated in ERAic. However, ERAic significantly over-predicted the offshore rainfall amount in the South China Sea. In addition, the patch of simulated rainfall along east coast of Peninsular Malaysia does not extend further south (Figure 5(d)). In ERAbc (Figure 5(e)), the location of the rainfall is comparable to CNTL, but the intensity is noticeably weaker. Overall, this experiment shows that the boundary condition uncertainty does have some notable impact on the forecast, which could lead to the suppression of strong rainfall convergence. In a previous study by Zhang et al. (2006), experiments using different initial data resulted in significant differences in both location and intensity of simulated rainfall, while different boundary conditions essentially produced no significant difference in the simulated rainfall, except for a reduction in intensity. Hence, the findings of the ERAic and ERAbc experiments in this study appear to be consistent with that of Zhang et al. (2006).

As in Zhang et al. (2006), different errors associated with different products in model initialisations (ERAint vs. GFS) influence the quality of the forecast differently. However, as stated in Zhang et al. (2006), a minimal impact of boundary conditions on the intensity and location of rainfall could also be associated with the large distance from the lateral boundary to the primary region of interest. In order to provide a quantitative measure of different factors on forecast quality, the error growth in the simulations in the context of practical predictability was further investigated by examining the difference of total energy (DTE) between the simulation experiments with respect to the CNTL, using the formula of Zhang et al. (2003):

$$
D T E=1 / 2 \sum\left(U_{i j k}^{\prime 2}+V_{i j k}^{\prime 2}+\kappa T_{i j k}^{\prime 2}\right)
$$

where U', V', and T' are the differences in wind components and temperatures between two simulations, $\kappa=C_{p} / T_{r}\left(C_{p}\right.$ $=1005.7 \mathrm{Jkg}^{-1} \mathrm{~K}^{-1}$ and the reference temperature $\left.T_{r}=287 \mathrm{~K}\right)$, and $\mathrm{i}, \mathrm{j}$, and $\mathrm{k}$ run over the $\mathrm{x}, \mathrm{y}$, and $\sigma$ grid points.

Figure 6 shows the DTE of four different aspects of practicability. In addition, although the intrinsic predictability aspect is not investigated in this study, the DTE of the perturbation experiment of CNTL (PrPERT) was also computed to provide comparison and a basis for future study. Overall, it can be seen that the highest DTE was associated with the CPS experiment (PrCPS). Experiments using different initial conditions (PrERAic) provided the second-highest DTE, while the third-largest error came from the experiment of different boundary conditions (PrERAbc). The initial perturbation experiment (PrPERT) showed slightly lower error than PrERAbc. However, it appears that the resolution experiment (PrRESe6) had the lowest DTE. There is a notable difference in terms of the

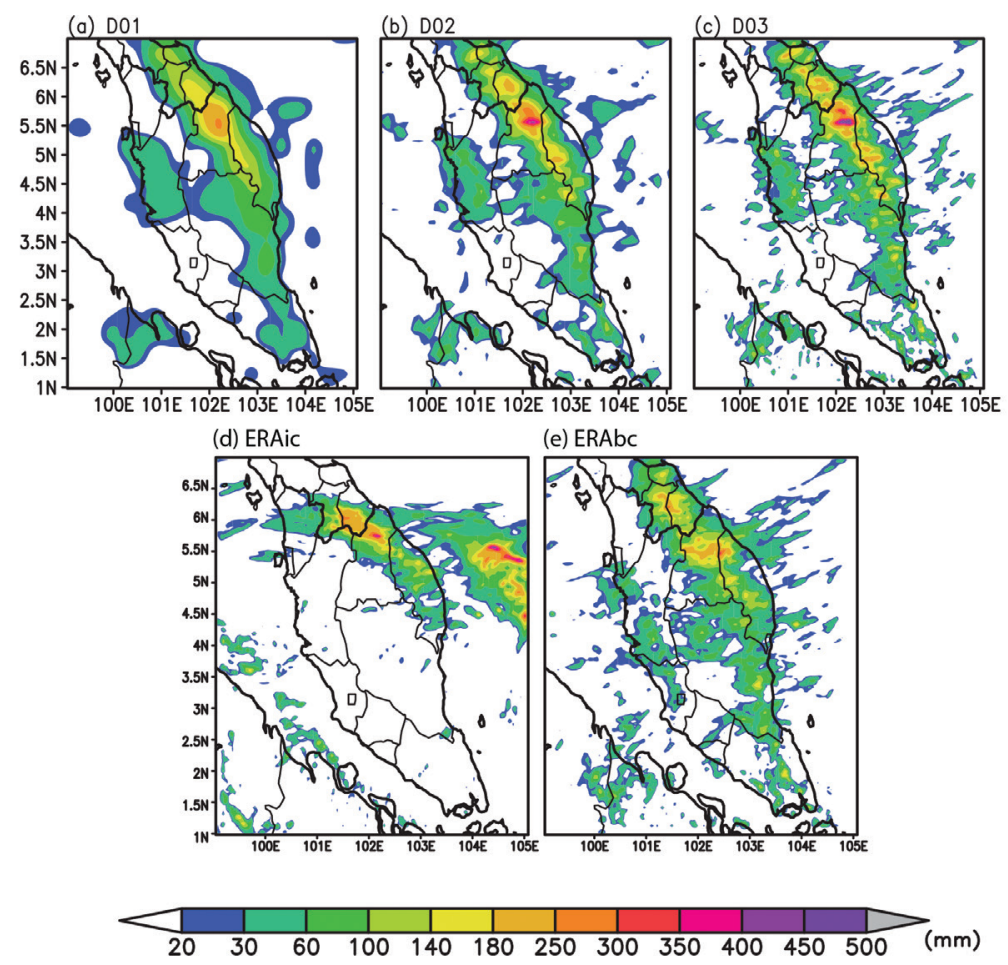

FIGURE 5. The $24 \mathrm{~h}$ accumulated rainfall (mm) for (a) RES1, (b) RES2,

(c) RCTL, (d) ERAic, and (e) ERAbc 


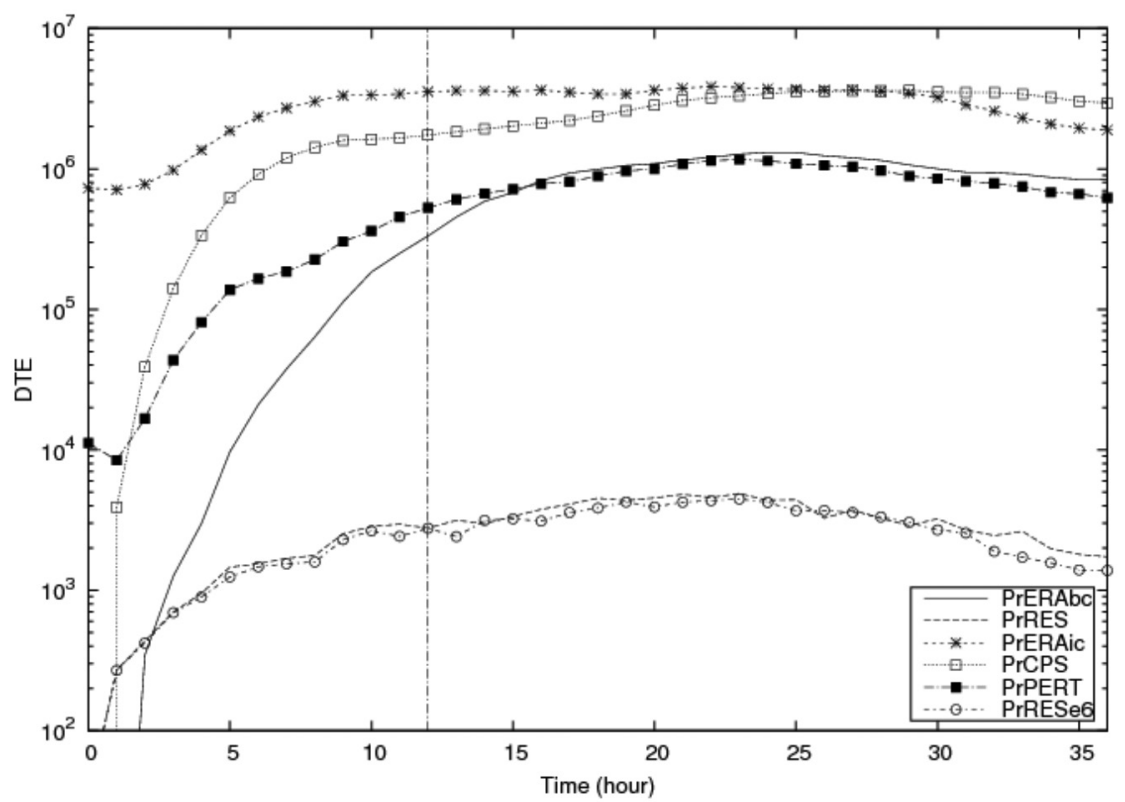

FIGURE 6. Evolution of DTE $\left(\mathrm{m}^{2} \mathrm{~s}^{-2}\right)$ between experiments RES1 and RCTL (PrRESe6), between experiments from D01 (in CNTL) and CNTL (PrRES), between ERAic and CNTL (PrERAic), between ERAbc and CNTL (PrERAbc), between BMJcps and CNTL (PrCPS), and between PERT and CNTL

$($ PrPERT). The vertical dotted line $($ time $=12 \mathrm{~h})$ indicates the spin up time of the model run

relative magnitude of DTE from that reported by Zhang et al. (2006), in which the lowest DTE was associated with the perturbation experiment. However, in this study, the resolution experiment appears to have the smallest DTE. In Zhang et al. (2006), resolution was attributed to large DTE since increasing the resolution did not increase the accuracy of the forecast. In fact, their high-resolution simulation completely failed to forecast the rainfall episode. On the contrary, this study shows that the rainfall episode was reasonably forecasted both at $36 \mathrm{~km}$ (D01) and $4 \mathrm{~km}$ (D03) resolutions. In fact, improvements can be seen in the 4 $\mathrm{km}$ simulation, especially in term of maximum rainfall. Hence, the DTE associated with resolution was much lower compared with those of other aspects.

For the grid resolution experiment, the DTE was calculated with respect to the RCTL. However, as shown, there is only a small difference if the DTE were to be calculated with respect to CNTL rather than RCTL (Figure 6). This implies that the use of MKF vs. explicit (i.e. no CPS scheme) provided no significant difference at $4 \mathrm{~km}$ resolution. The error growth of ERAbc compared to CNTL appears much larger during the spin-up time compared with that of the ERAic, although at the $36 \mathrm{~h}$ forecast the ERAic DTE was double that of the ERAbc. However, Figure 6 also shows that the DTE associated with different initial analyses (PrERAic) may lead to relatively larger errors compared to the PrPERT. Models are sensitive to the initial conditions, where small errors in the initial state would lead to bigger changes to the forecast (Nielsen-Gammon et al. 2005; Zheng et al. 2016). However, errors in the initial conditions may originate from the use of different analysis products or inaccuracy in the initial condition. This study suggests that the use of different analysis products may lead to larger errors. Forecast quality may be improved with even a small improvement in initial conditions through data assimilation (Rabier et al. 1996). Selecting the appropriate CPS is also important, as the DTE associated with the CPS experiment is the largest, which is consistent with Zhang et al. (2006). Furthermore, the importance of an appropriate CPS in correctly forecasting the extreme rainfall episodes over Peninsular Malaysia has been previously demonstrated in Ardie et al. (2012), Salimun et al. (2010) and Yavinchan et al. (2011).

Based on the sensitivity experiment, the highest DTE was contributed by CPS difference, followed closely by different initial conditions (Figure 6). Previous studies (Litta et al. 2007; Nielsen-Gammon et al. 2005; Salimun et al. 2010; Yavinchan et al. 2011; Zhang et al. 2006; Zheng et al. 2016) have also demonstrated that both CPS and initial conditions contributed to the largest variations in predicted rainfall. The third-highest DTE was contributed by the different boundary conditions, while the different grid resolutions contributed the least (Figure 6). The smallest DTE associated with the resolution difference could be associated with use of the MKF in which grid resolution dependencies were applicable in this scheme. Three updated parameters in the CPS namely the dynamic adjustment time scale, grid scale vertical velocity and entrainment effect show improvement in the intensity and patterns of the precipitation and reduce excessive precipitation biases (Zheng et al. 2016). Moreover, Mahoney (2016) showed that KF scheme produced far less precipitation compared to the MKF scheme in the simulation of $4 \mathrm{~km}$ horizontal grid spacing of 2013 Colorado Front 
Range floods. Zhang et al. (2006) also showed CPS and initial condition differences contribute to the highest error. Nevertheless, resolution differences also produced high errors due to the inability to predict the event in the higher resolution run (Zhang et al. 2016).

\section{CONCLUSION}

The practical predictability of the 17 December 2014 heavy rainfall episode was investigated using the WRF Model of $36 \mathrm{~km}, 12 \mathrm{~km}$ and $4 \mathrm{~km}$ nested grid resolution. The results suggested that the intensity and location of predicted rainfall is affected largely by the treatment of deep convection in the simulations. The combination of MKF scheme for the outer domains, and explicitly resolved convective process in the innermost domain in EXP5 gives the best consistency of simulated rainfall with the observations.

Further experiments of predictability dependency on grid resolution, initial and boundary conditions, and convection schemes showed that the largest uncertainties in the forecast come from the convection schemes and initial analysis. The effects of boundary conditions and grid resolution can be considered secondary. This suggests that convection scheme and model initialisation aspects should be given the utmost priority in order to improve forecasting of extreme rainfall events. It was also found that the higher grid resolution provided the best simulation and forecast. However, these results are based solely on the simulations of a single extreme rainfall event. Hence, further research on different extreme rainfall cases may be needed for generalisation of the results. Intrinsic predictability aspects should also be investigated to understand how overall performance of model in forecasting heavy rainfall events could be further improved.

\section{ACKNOWLEDGEMENTS}

The authors would like to thank the Malaysian Meteorological Department for providing the rainfall station data used in this study. The first author also would like to express her gratitude to the Public Service Department of Malaysia for the scholarship. This research is also funded by the MOHE FRGS/1/2017/WAB05/UKM/01/2 grant.

\section{REFERENCES}

Arakawa, A. \& Jung, J.H. 2011. Multiscale modeling of the moistconvective atmosphere-A review. Atmospheric Research 102(3): 263-285.

Ardie, W.A., Sow, K.S., Tangang, F., Hussin, A.G., Mahmud, M. \& Juneng, L. 2012. The performance of different cumulus parameterization schemes in simulating the 2006/2007 southern Peninsular Malaysia heavy rainfall episodes. Journal of Earth System Science 121(2): 317-327.

Chen, T.C., Tsay, J.D., Yen, M.C. \& Matsumoto, J. 2013. The winter rainfall of Malaysia. Journal of Climate 26(3): 936958.
Dudhia, J. 1989. Numerical study of convection observed during the winter monsoon experiment using a mesoscale twodimensional model. Journal of the Atmospheric Sciences 46(20): 3077-3107.

Dudhia, J. 1996. A multi-layer soil temperature model for MM5. Preprints, The Sixth PSU/NCAR Mesoscale Model Users' Workshop. pp. 22-24.

Field,C.B., Barros, V., Stocker, T.F. \& Dahe, Q. 2012. Managing the Risks of Extreme Events and Disasters to Advance Climate Change Adaptation: Special Report of the Intergovernmental Panel On Climate Change. Cambridge: Cambridge University Press.

Han, J. \& Pan, H.L. 2011. Revision of convection and vertical diffusion schemes in the NCEP global forecast system. Weather and Forecasting 26(4): 520-533.

Hong, S.Y., Dudhia, J. \& Chen, S.H. 2004 . A revised approach to ice microphysical processes for the bulk parameterization of clouds and precipitation. Monthly Weather Review 132(1): 103-120.

Hong, S.Y., Noh, Y. \& Dudhia, J. 2006. A new vertical diffusion package with an explicit treatment of entrainment processes. Monthly Weather Review 134(9): 2318-2341.

Huffman, G.J., Bolvin, D.T., Nelkin, E.J., Wolff, D.B.,Adler, R.F., Gu, G., Hong, Y., Bowman, K.P. \& Stocker, E.F. 2007. The TRMM multisatellite precipitation analysis (TMPA): Quasiglobal, multiyear, combined-sensor precipitation estimates at fine scales. Journal of Hydrometeorology 8(1): 38-55.

Janjic, Z.I. 1994. The step-mountain eta coordinate model: Further developments of the convection, viscous sublayer, and turbulence closure schemes. Monthly Weather Review 122(5): 927-945.

Jankov, I., Gallus Jr., W.A., Segal, M., Shaw, B. \& Koch, S.E. 2005. The impact of different WRF model physical parameterizations and their interactions on warm season MCS rainfall. Weather and Forecasting 20(6): 1048-1060.

Juneng, L., Tangang, F.T. \& Reason, C.J.C. 2007. Numerical case study of an extreme rainfall event during 9-11 December 2004 over the east coast of Peninsular Malaysia. Meteorology and Atmospheric Physics 98(1-2): 81-98.

Kain, J.S. 2004. The Kain-Fritsch convective parameterization: An update. Journal of Applied Meteorology 43(1): 170-181.

Kain, J.S. \& Fritsch, J.M. 1993. Convective parameterization for mesoscale models: The Kain-Fritsch scheme. In The Representation of Cumulus Convection in Numerical Models, edited by Emanuel, K.A. \& Raymond, D.J. Boston: American Meteorological Society. pp. 165-170.

Kerkhoven, E., Gan, T.Y., Shiiba, M., Reuter, G. \& Tanaka, K. 2006. A comparison of cumulus parameterization schemes in a numerical weather prediction model for a monsoon rainfall event. Hydrological Processes 20(9): 1961-1978.

Kumar, A., Dudhia, J., Rotunno, R., Niyogi, D. \& Mohanty, U.C. 2008. Analysis of the 26 July 2005 heavy rain event over Mumbai, India using the Weather Research and Forecasting (WRF) model. Quarterly Journal of the Royal Meteorological Society 134(636): 1897-1910.

Litta, A.J., Chakrapani, B. \& Mohankumar, K. 2007. Mesoscale simulation of an extreme rainfall event over Mumbai, India, using a high-resolution MM5 model. Meteorological Applications 14(3): 291-295.

Mahoney, K.M. 2016. The representation of cumulus convection in high-resolution simulations of the 2013 Colorado front range flood. Monthly Weather Review 144(11): 4265-4278. 
Mlawer, E.J., Taubman, S.J., Brown, P.D., Iacono, M.J. \& Clough, S.A. 1997. Radiative transfer for inhomogeneous atmospheres: RRTM, a validated correlated $\square \mathrm{k}$ model for the longwave. Journal of Geophysical Research: Atmospheres 102 (D14): 16663-16682.

Nielsen-Gammon, J., Zhang, F., Odins, A. \& Myoung, B. 2005. Extreme rainfall in Texas: Patterns and predictability. Physical Geography 26(5): 340-364.

Ooi, S.H., Samah, A.A., Chenoli, S.N., Subramaniam, K. \& Ahmad Mazuki, M.Y. 2017. Extreme Rainstorms that caused devastating flooding across the East Coast of Peninsular Malaysia during November and December 2014. Weather and Forecasting 32(3): 849-872.

Rabier, F., Klinker, E., Courtier, P. \& Hollingsworth, A. 1996. Sensitivity of forecast errors to initial conditions. Quarterly Journal of the Royal Meteorological Society 122(529): 121-150.

Salimun, E., Tangang, F. \& Juneng, L. 2010. Simulation of heavy precipitation episode over eastern Peninsular Malaysia using MM5: Sensitivity to cumulus parameterization schemes. Meteorology and Atmospheric Physics 107(1-2): 33-49.

Skamarock, W.C., Klemp, J.B., Dudhia, J., Gill, D.O., Barker, D.M., Duda, M.G., Huang, X.Y., Wang, W. \& Powers, J.G. 2008. A Description of the Advanced Research WRF Version 3. National Center for Atmospheric Research Boulder Co Mesoscale and Microscale Meteorology Div.

Tangang, F., Supari, S., Chung, J., Cruz, F., Salimun, E., Ngai, S., Juneng, L., Santisirisomboon, J., Santisirisomboon, J., Ngo_Duc, T., Tan, P.V., Narisma, G., Singhruck, P., Gunawan, D., Aldrian, E., Sopaheluwakan, S., Nikulin, G., Yang, H., Remedio, A.R.C., Sein, D. \& Hein-Griggs, D. 2018. Future changes in annual precipitation extremes over Southeast Asia under global warming of $2^{\circ} \mathrm{C}$. APN Science Bulletin 8(1). doi:10.30852/sb.2018.436.

Tangang, F., Farzanmanesh, R., Mirzaei, A., Supari, Salimun, E., Jamaluddin, A.F. \& Juneng, L. 2017. Characteristics of precipitation extremes in Malaysia associated with El Niño and La Niña events. International Journal of Climatology 37(S1): 696-716.

Tangang, F.T., Liew, J., Salimun, E., Kwan, M.S., Loh, J.L. \& Muhamad, H. 2012. Climate change and variability over Malaysia: Gaps in science and research information. Sains Malaysiana 41(11): 1355-1366.

Tangang, F.T., Juneng, L., Salimun, E., Vinayachandran, P.N., Seng, Y.K., Reason, C.J.C., Behera, S.K. \& Yasunari, T. 2008. On the roles of the northeast cold surge, the Borneo vortex, the Madden-Julian Oscillation, and the Indian Ocean Dipole during the extreme 2006/2007 flood in southern Peninsular Malaysia. Geophysical Research Letters 35(14): L14S07.
Taraphdar, S., Mukhopadhyay, P., Leung, L.R., Zhang, F., Abhilash, S. \& Goswami, B.N. 2014. The role of moist processes in the intrinsic predictability of Indian Ocean cyclones. Journal of Geophysical Research: Atmospheres 119(13): 8032-8048.

Yavinchan, S., Exell, R.H.B. \& Sukawat, D. 2011. Convective parameterization in a model for the prediction of heavy rain in Southern Thailand. Journal of the Meteorological Society of Japan 89A: 201-224.

Zhang, F., Odins, A.M. \& Nielsen-Gammon, J.W. 2006. Mesoscale predictability of an extreme warm-season precipitation event. Weather and Forecasting 21(2): 149-166.

Zhang, F., Snyder, C. \& Rotunno, R. 2002. Mesoscale predictability of the "surprise" snowstorm of 24-25 January 2000. Monthly Weather Review 130(6): 1617-1632.

Zhang, F., Snyder, C. \& Rotunno, R. 2003. Effects of moist convection on mesoscale predictability. Journal of the Atmospheric Sciences 60(9): 1173-1185.

Zheng, Y., Alapaty, K., Herwehe, J.A., Del Genio, A.D. \& Niyogi, D. 2016. Improving high-resolution weather forecasts using the Weather Research and Forecasting (WRF) Model with an updated Kain-Fritsch Scheme. Monthly Weather Review 144(3): 833-860

Wan Maisarah Wan Ibadullah, Fredolin Tangang*, Liew Juneng \& Ahmad Fairudz Jamaluddin

Centre for Earth Sciences and Environment

Faculty of Science and Technology

Universiti Kebangsaan Malaysia

43600 UKM Bangi, Selangor Darul Ehsan

Malaysia

Wan Maisarah Wan Ibadullah \& Ahmad Fairudz Jamaluddin Malaysian Meteorological Department

Jalan Sultan

46667 Petaling Jaya, Selangor Darul Ehsan

Malaysia

*Corresponding author; email: tangang@ukm.edu.my

Received: 31 March 2019

Accepted: 15 August 2019 